\title{
Investing in Real Estate Investments Trusts (REITs) Provides Performance and Risk Diversification Benefits: A Malaysia and Japan Analysis
}

David Ching Yat, Ng, Teck Chai, Lau, Shubatra Shanmugaretnam, Fitriya binti Abdul Rahim

To Link this Article: http://dx.doi.org/10.6007/IJARBSS/v11-i6/10172

DOI:10.6007/IJARBSS/v11-i6/10172

Received: 10 April 2021, Revised: 11 May 2021, Accepted: 25 May 2021

Published Online: 13 June 2021

In-Text Citation: (Ng et al., 2021)

To Cite this Article: Ng, D. C. Y., Lau, T. C., Shanmugaretnam, S., \& Rahim, F. binti A. (2021). Investing in Real Estate Investments Trusts (REITs) Provides Performance and Risk Diversification Benefits: A Malaysia and Japan Analysis. International Journal of Academic Research in Business and Social Sciences, 11(6), 453474.

Copyright: (c) 2021 The Author(s)

Published by Human Resource Management Academic Research Society (www.hrmars.com)

This article is published under the Creative Commons Attribution (CC BY 4.0) license. Anyone may reproduce, distribute, translate and create derivative works of this article (for both commercial and non-commercial purposes), subject to full attribution to the original publication and authors. The full terms of this license may be seen

at: http://creativecommons.org/licences/by/4.0/legalcode

Vol. 11, No. 6, 2021, Pg. 453 - 474

http://hrmars.com/index.php/pages/detail/IJARBSS

JOURNAL HOMEPAGE

Full Terms \& Conditions of access and use can be found at http://hrmars.com/index.php/pages/detail/publication-ethics 


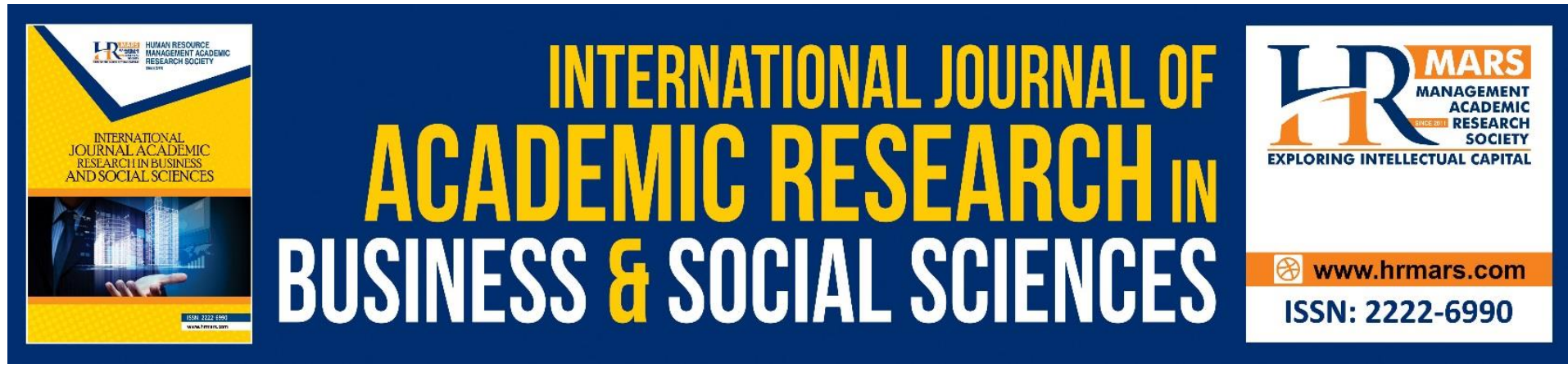

\title{
Investing in Real Estate Investments Trusts (REITs) Provides Performance and Risk Diversification Benefits: A Malaysia and Japan Analysis
}

\author{
David Ching Yat, $\mathrm{Ng}$
}

Faculty of Accountancy and Management, Universiti Tunku Abdul Rahman

Teck Chai, Lau

Southampton Business School University of Southampton Faculty of Accountancy and Management

Shubatra Shanmugaretnam

Faculty of Accountancy and Management, Universiti Tunku Abdul Rahman

\section{Fitriya binti Abdul Rahim}

Faculty of Accountancy and Management, Universiti Tunku Abdul Rahman

\begin{abstract}
This study analyses the effectiveness of risk diversification and investment performance between M-REITs' and J-REITs' by comparing the diversification measures (unsystematic risk divided by total risk and one-minus $\mathrm{R}$ squared) including their respective Sharpe Ratio, Treynor Ratio and Jensen's Alpha calculated on each REITs. The study period for M-REITs' and J-REITs extends from 2008 to 2017. Resultsindicate that M-REITs' performed better than J-REITs' in terms of Sharpe ratio, Treynor ratio, and Jensen's Alpha. Total risk of J-REITs' are higher than M-REITs'. The Beta values for both M-REITs' and J-REITs' are less than one, implying that both categories of REITs are less risky than the market index. M-REITs' have lower R-Squared values than S-REITs', which suggest that M-REITs' are poorly diversified against J-REITs' and therefore, M-REITs' have more diversification opportunities. The diversification measures computed for M-REITs' are higher than J-REITs' and would imply that M- REITs' have better rate of returns if M-REITs' diversify their risk (higher risk diversification benefits). The findings from this study aims to help investors to make better investment decision when investing in M-REITs' and J-REITs'. The findings from this study aims to assist investors determine better investment decisions when considering investing in M-REITs' and J-REITs'.
\end{abstract}

Keywords: M=REITs, J-REITs', Performance, Risk Diversification Benefits. 


\section{Introduction}

This research's main focus is to compare/investigate the performance and risk diversification benefits of Real Estate Investment Trust (REITs) between Malaysia andJapan. This research evaluates the REITs' performance and risk benefits for Malaysia and Japan by studying their weekly share price from the year 2008 to year 2017, a 10 years study. Extracting secondary data from weekly share price returns, financialanalytics tools like beta measure ( $\beta \beta)$, R-squared, Sharpe Ratio, Treynor Ratio, and Jensen Alpha will be calculated and applied as measuring tools.

\section{Hypotheses of Study}

\section{Hypothesis 1}

HHo0: M-REITs' $\beta>$ J-REITs' $\beta$ (M-REITs' have higher Beta [market risk] compared to J-REITs)

HH11: M-REITs' $\beta<$ J-REITs' $\beta$ (M-REITs' have lower Beta [market risk] compared to J- REITs)

\section{Hypothesis 2}

HHo0: M-REITs' Rd < J-REITs' Rd (M-REITs have lower risk diversification benefits compared to J-REITS)

HH11: M-REITs' Rd > J-REITs' Rd (M-REITs have higher risk diversification benefits compared to J-REITS)

\section{Hypothesis 3}

HHo0: M-REITs' SR < J-REITs' SR (M-REITs have lower Sharpe ratio compared to J- REITs)

HH11: M-REITs' SR > J-REITs' SR (M-REITs have higher Sharpe ratio compared to J- REITs)

\section{Hypothesis 4}

HHoo: M-REITs' TR < J-REITs' TR (M-REITs have lower Treynor ratio compared to J- REITs) HH11: M-REITs' TR > J-REITs' TR (M-REITs have higher Treynor ratio compared to J- REITs)

Hypothesis 5:

HHoo: M-REITs' ai < J-REITs' ai (M-REITs have lower Jensen's Alpha compared to J- REITs)

HH11: M-REITs' ai > J-REITs' ai (M-REITs have higher Jensen's Alpha compared to J-REITs)

\section{Overview}

Previous studies indicate that there is a general consensus that REITs worldwide largely produce positive returns and outperform their national indices, according to a study of 204 REITs from different countries over a 20-year period by Brounen and de Koning (2013). This is further corroborated by Moss et al. (2015), who found that on a global scale, investing in REITs can be beneficial to both dedicated REIT-only portfolios and multi-asset portfolios in the form of enhanced returns, diversification and reduced risk.

However, some studies have found exceptions. In a study of Nigerian REITs, Olanrele et al. (2015) found that despite the generally superior performance of REITs, Nigerian REITs underperformed, suggesting that the benefits of REITs may not be absolute, and may depend on other factors. Furthermore, there was evidence to suggest that this may not be isolated solely to developing countries with emerging economies like Nigeria, as a study conducted by $\mathrm{Ng}$ et al. (2018) showed that even some REITs in Singapore, a well-developed high-income country can underperform. 


\section{Malaysian Context- Reits Performance and Risks}

$\mathrm{Ng}$ et al. (2018) analysed the performance of sixteen MalaysianREITs from year 2007 to 2016 by applying three standard performance measurement tools: Sharpe Ratio, Treynor Ratio and Jensen's Alpha to estimate the risks, returns andperformance of each M-REIT. The study concluded that investing in M-REITs will provide a preferable return because every one of the M-REITs outperformed the market benchmark during the time period. This is further reinforced in a study by Olanrele et al. (2014), who analysed the performance of three M-REITs over a five-yearperiod (2008-2014) using a hedonic regression model. The study found that all the M-REITs outperformed the market index throughout the time period, albeit with some sectoral capacity underperformance. The results of both studies are generally consistent with Brounen and de Koning's (2013) results that concluded REITs tend to provide a higher return than the market index and saving accounts. Low and Johari (2014) studied the performance and risk diversification of 12 M-REITs throughout the 2007-2012 period utilizing Jensen's Alpha, Treynor Ratio, and the Sharpe Ratio. Additionally, theyutilized an alternative approach to performance evaluation known as the M-squared measure, developed from Markowitz's (1952) portfolio theory, which focused on the idea of manipulating leverage to accomplish the best fund performance for any risk level. The results from the study indicated that the total risk of Malaysian REITs came mostly from the unsystematic risk component, which indicates significant opportunitiesto diversify. The study also highlights the importance of accounting for risk in performance analyses of REITs.

To investigate the risk diversification impact of M-REITs on portfolio diversification, Jalil et al. (2015) analysed expected return, standard deviation, and the efficient frontier of $13 \mathrm{M}$-REITs, with the results showing that the addition of M-REITs to an investment portfolio portrays significant risk diversification benefits. The research also indicates that although REITs are riskier than direct real estate investment, they can potentially bring higher returns given their volatility toward upper part of the efficiencyfrontier, making them the optimal choice for aggressive investors. The overall results of the study goes on to conclude that REITs can be especially beneficial during periods of economic downturn due to their perfectly negative correlation to the general market, contradicting the findings of the study by Chiang et al. (2013).

A study by Hamzah and Rozali (2010) that also utilized the three measures methods (Sharpe Ratio, Treynor Ratio and Jensen Alpha) found that the risk-adjusted performance of M-REITs varied throughout the time period under study, and that the systematic risk of M-REITs in general were considerably higher than the market duringeconomic crisis compared to the period immediately after the crisis, during which time the systematic risks became significantly lower.

\section{Japanese Context- Reits Performance and Risks}

Japan was one of the first countries in Asia to establish a REIT market, with the first J- REIT being listed in 2001. It has since become one of the largest and most well- developed REIT markets in the world, and the largest in Asia (Miyakoshi et al., 2016). A study by Su et al. (2010) examined and compared the characteristics of Japanese REIT with United States' REIT. They found that J-REITs generally have "hybrid" characteristics, featuring traits found in both stocks and bonds. Pham (2012) examined the dynamics of returns and volatility in the Asian REIT marketsusing the EGARCH model, the results indicated that the returns in the Japanese REITs 
market has significant influence on returns in emerging REITs markets, such as those in Malaysia and Taiwan. The study concluded that while this is true for mean returns, it is not true for REIT market volatility, where Japan was affected more by other Asian REIT markets, making it a returns transmitter but a volatility receiver. This is consistent with the findings from a study by Nawawi et al (2010), which found that the Japanese REIT market had some influence on Malaysian REITs. An empirical study on the risk-adjusted performance and portfolio diversification benefits of sub-sector J- REITs was done by Cho (2017). The research utilized the Sharpe Ratio analysis, risk- return ratio and reward to risk ratio to assess riskadjusted return performance, and correlation coefficient analysis to assess diversification benefits for seven sub-sector J- REITs throughout the period from 2010-2015. The results of the study indicated that sub-sector REITs such as hotel and industrial REITs outperformed traditional benchmark REITs, while also finding that J-REITs have generally low diversification benefits given their close correlation to the Japanese stock market. On the risk-adjusted performance of J-REITs as a whole, an empirical study was done by Newell and Peng (2012), where the risk-adjusted performance and diversification benefits of J-REITs from 2001 to 2011 were analysed by using the Sharpe Ratio. The research found that over the sample period, JREITs provided the best risk-adjusted performance comparedto bonds, property companies, and stocks. The study concluded that a mixed-asset portfolio including J-REITs would outperform one without J-REITs, highlighting the benefits of J-REITs. Furthermore, the study found that the risk-adjusted performance of J-REITs was even better after the financial crisis period compared to before, which may imply J-REITs' resilience to financial crises. However, according to Miyakoshi et al. (2016), the Japanese REIT market remains vulnerable to two kinds of so-called "shocks", the first being financial market shock caused by international financial crises, while the second relates to natural disasters which commonly plague Japan, such as tsunamis and earthquakes. Despite that, a study by Jain (2017) suggests that J-REITs may actually be less affected by financial crises compared to non-REIT common stocks on the Tokyo Stock Exchange. Another study relating to the subject wasdone by Shimizu et al. (2015), which utilized a new method to estimate commercial property price indexes using J-REIT data. They found that the price of REITs could be useful to gauge the commercial property prices, implying a degree of correlation between the two.

\section{Data Collection}

The sampling data consists of 16 M-REITs and 57 J-REITs from the period 2008 to 2017 for both countries. The same 10-year range was used to ensure a consistent comparison amongst both countries. The matrix used to compare both REITs was statedabove and will be further explained below. This study extracts secondary data from verified and credible sources as well as the application of well-justified and tested mathematical formulas to obtain the required data.

\section{Secondary data Collection}

The weekly stock prices of all the 16 M-REITs' and 57 J-REIT's listed from the year 2008 to year 2017 were extracted from Bloomberg terminal. The weekly share prices ofM-REITs' and JREITs' were used to compare against the indexes from KLPR KL Property Index and Tokyo Stock Exchange REIT Index. The reason why KLPR KL Property Index was used is because of the absence of a REIT index generated in Bursa Malaysia. In other words, the best alternative that can be used as a metric to compare 
with M-REITs would be the KLPR KL Property Index, Malaysia' property index.

The weekly returns of the $16 \mathrm{M}$-REITs and $57 \mathrm{~J}$-REITs were calculated using thefollowing formulas:

RR $=\underline{\text { PPtt-PPtt-1 }}$ XX 100

where, $\quad$ tt $\quad P P_{t t-1}$

$\mathrm{Rt}=\mathrm{M}-\mathrm{REIT} / \mathrm{J}-\mathrm{REIT}$ stock price for week $\mathrm{t}$

$\mathrm{Pt}=$ Closing share price of M-REIT/J-REIT at the chosen day of week $\mathrm{t}$

Pt-1 = Closing share price of M-REIT/J-REIT at the chosen day of week before week $t$ The weekly returns for KLPR KL Property Index and Tokyo Stock Exchange REITs Index were calculated with the following formula:

RR

tt-1

where,

Rindex $=$ Index for week $\mathrm{t}$

It $=$ Closing index value on chosen day of week $t$

It-1 = Closing index value on chosen day of week before week $\mathrm{t}$

\section{Calculating Reits' Risk Features}

The standard deviation of each REIT was calculated before being used to determine the volatility of each REIT against the respective property index, namely the KLPR KL Property Index for M-REITs and the Tokyo Stock Exchange REITs Index for J-REITs.The REITs' standard deviation is a statistical measure of the volatility of their individualsample weekly return. Risk averse investors may prefer an investment portfolio with lower standard deviation compared

to its benchmark value as it implies lower volatility, and therefore lower risk or uncertainty within the portfolio.

ii 2

$\sum(i i-\mu \mu)$

where,

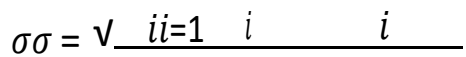

$i i-1$

$\mathrm{X} i=$ weekly return of $\mathrm{REITS}$

$\mu=$ the mean return of REITs for the year $(\%) n=$ sample period (years)

Besides that, the total risk (comprising of market risk and unsystematic risk) of each of the $57 \mathrm{~J}$-REITs and $16 \mathrm{M}$-REITs were calculated and compared with the followingformula: $\sigma \sigma^{2}=\beta \beta^{2} . \sigma \sigma^{2}+\sigma \sigma^{2}$

where,

$\sigma^{2}=$ Total risk for REITs

iii $\quad \mathrm{mm} \quad$ ii

$\beta^{2}=$ Square of Beta of REITs 
$\sigma \mathrm{m}^{2}=$ Variance of return of the market portfolio $\beta \mathrm{i}^{2} \sigma \mathrm{m}^{2}=$ Systematic risk of REITs

$\sigma \mathrm{e}^{2}=$ Unsystematic risk of REITs

Diversification can be defined as "the process of allocating capital in order to reduce the exposure to risk" (Ng et al., 2018). In other words, diversification is a way for investors to reduce volatility by mixing a wide variety of investments within a portfolio.

A REIT's risk diversification benefits can be determined by the ratio of its unsystematic risk to total risk, which serves as a measure of risk "diversifiability" (Kim et al., 2002). This diversifiability measure can be determined in one of two ways. Thefirst method is by simply dividing the unsystematic risk over total risk. The closer the ratio is to 0 , the more insignificant the unsystematic risk component of the REIT. Conversely, the closer the ratio is to 1 , the more significant the unsystematic risk component of the REIT.

The first method of calculating the Diversifiability Measure is shown below:

$\sigma 02$

where, DDiiDDiiDDDDiDDiidDDDiiliittDD MMiiDDDOMDDii $=$ ii ii

$\sigma o i i^{2}=$ Unsystematic Risk of REITs

$\sigma \sigma^{2}=$ Total Risk of REITs

The second method is by using the following formula: one minus R-squared ( $1-R-$ squared). The further the ratio is from 0 , the more unsystematic risk remains in the portfolio to be diversified away. However, if a portfolio's Diversifiability Measure has a ratio that is close to 0 , it has little unsystematic risk remaining and is not diversifiable. The second method of calculating the Diversifiability Measure is shown below:

DDiDDiidDDDiDDiidDDDilliittDD MMiiDDDDMDDii $=1-R R^{2}$

where,

$\mathrm{R}^{2}=\mathrm{R}$-squared

The formula for calculating the R-Squared value of REITs is shown below:

$\beta \beta . \sigma \sigma$

where,

$R R^{2}=i_{i i}^{i m m}$
$i \sigma^{2}$

$R R^{2}=$ R-Squared 
$\beta \beta^{2}=$ Square of portfolio's beta

$\sigma^{2}=$ Variance of return of the market portfolio $\beta^{2} . \sigma^{2}=$ Systematic risk component of REITs $\sigma$

$2=$ Total risk i

In addition to being used to calculate each REIT's diversifiability measure, the R- squared of each REIT is also used to examine the market movement of each REIT that can be predicted by the movement of the portfolio benchmark. In sum, the R-squared demonstrates the relationship between the total risk and systematic risk, as it explains how much of the total risk is affected by systematic risk. The higher the value of $\mathrm{R}$ - squared, the higher the likelihood that the REIT moves in the same direction as the market index, indicating that the inherent total risk within the REIT is affected by the systematic risk. Conversely, if the R-squared has a low value, it shows that the REIT does not move along with the market index, indicating that the REIT does not behave much like the market index.

\section{Calculating Reits' Performance (Sharpe Ratio, Treynor Ratio, and Jensen's Alpha)}

The risk-adjusted performance measures of the REITs are computed using the Sharpe Ratio, Treynor Ratio and Jensen's Alpha to determine:

how the REITs are performing against the projected risk, and

the possible excess return from each REIT against the market index.

The Sharpe Ratio calculates the return generated in excess of the risk-free rate of return per unit of standard deviation in each REIT. The standard deviation is used to present the diversity of the returns over a sampling period.

The formula for calculating the Sharpe Ratio is shown below:

$S S R R=D D i i-D D D D$

$\sigma \sigma i i$

where,

SR = Sharpe Ratio

$\mathrm{ri}=$ average return of REITs $\mathrm{rf}=$ risk free rate of return

$\sigma \sigma i i=$ standard deviation of REITs

The higher the value of Sharpe Ratio, the more attractive the REIT's return is against the riskfree rate of return. A positive Sharpe Ratio value indicates returns generated in excess of the risk-free rate of return, while a negative Sharpe Ratio value indicates that the portfolio generates a lower return compared to the risk-free rate of return.

The Treynor Ratio is a performance metric for determining how much more return was earned for each unit of risk taken on by a portfolio (Treynor, 1965). Like the Sharpe Ratio, it is used to determine the additional profits earned as more risk is taken on. However, unlike the Sharpe ratio, the Treynor utilizes $\beta$ (market risk) to measure volatility instead of total risk (standard deviation).

The formula for calculating the Treynor Ratio is shown below:

where,
$\mathrm{TR}=$ Treynor Ratio
$\mathrm{ri}=$ average return of REITsrf $=$ risk $^{\frac{\operatorname{rrff}}{\beta \beta i i}}$
free rate of return
$\beta \beta i=$ beta of portfolio

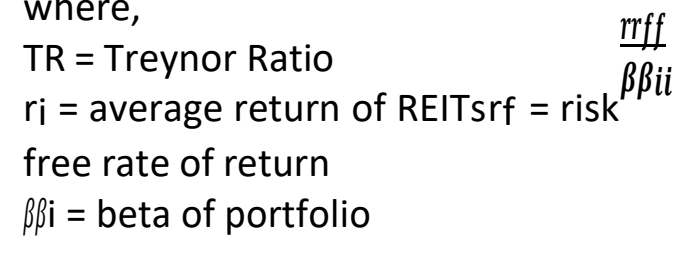


Generally, the higher of the Treynor ratio, the more attractive the return is, adjusted forthe level of risk taken. The higher the Treynor Ratio is, the greater the REIT's excess returns gained against the portfolio benchmark.

Jensen's Alpha is an evaluation tool used to determine the abnormal return on each REITover the expected or required return as determined by the capital asset pricing model (CAPM), given the REITs' beta and the average market return (Jensen, 1968). In sum, it utilizes the CAPM to estimate the rate of return based on market volatility by measuring the REITs' beta and comparing it with the market beta (Fama \& French, 2004).

The formula for calculating Jensen's Alpha is shown below:

aaii $=$ RRii $-[$ RRDD $+\beta \beta$ Bii $(R R m m-R R D D)]$

where,

$\alpha \mathbf{i i}=$ Jensen's Alpha for REITRi = return of REIT

$\mathrm{Rf}=$ risk free rate

$\beta \mathrm{i}=$ beta of portfolio

$\mathrm{Rm}=$ return of portfolio market

\section{Empirical Findings}

\section{Risk Features of Reits}

Table 2, Table 2.1 and Table 2.2 indicates the overall average weekly returns of the $16 \mathrm{M}$ REITs, calculated at approximately $0.2060 \%$ and the average return of all M-REITsactually performed much better than the KLPR KL Property Index, which stands at $0.0725 \%$. On the other hand, for the $57 \mathrm{~J}$-REITs, the overall average weekly returns stand at $0.1918 \%$, which also generated excess return against the Tokyo Stock ExchangeREIT Index of $0.0112 \%$. Comparing both M-REITs' and J-REIT's overall average weekly returns, M-REITs with $0.2060 \%$ actually performed slightly better than J- REITs' $0.1918 \%$, generating slightly more returns. The overall rate of return generated by J-REITs' is lesser than those in M-REITs' due to some of the J-REITs' such as Nippon Healthcare Investment Corporation, Healthcare \& Medical Investment Corporation, Nomura Real Estate Master Fund, Inc., and Mitsubishi Estate Logistics REIT Investment Corporation generated negative overall weekly returns and it vastly underperformed against the Tokyo Stock Exchange REIT Index of $0.0112 \%$. These reported negative average returns in the end of 2017 affected the average rate of return in the overall REITs market in Japan, whereas on the other hand, none of the $16 \mathrm{M}$ - REITs have negative weekly returns, which boosted the overall average weekly returnsof M-REITs. J-REITs' had a higher standard deviation of approximately $3.6384 \%$ as compared to M-REITs' approximately $2.0573 \%$. J-REITs achieved a significantly higher average return volatility in which it exceeded the Tokyo Stock Exchange REIT Index's average return volatility of approximately $2.5922 \%$. However, M-REITs achieved a lower average return volatility compared to the market index of KLPR KL Property Index, which is approximately $2.1952 \%$, slightly higher than M-REITs' $2.0573 \%$. The total risk is calculated using the squared of the average return volatility. For JREITs, it is calculated at approximately $15.12367 \%$ and it is significantly higher than M-REITs' calculated value at approximately $4.38548 \%$. Thus, concluded from thetotal risk value from both REITs is that both markets take a significantly different total risk. The total risk taken by J-REITs is approximately 3 times larger than M-REITs. In addition to that, the systematic risk of J-REITs fluctuates between from the lowest value approximately 1 to highest value 29 approximately, whereas the systematic risk of M- REITs is only lower than $1 \%$, where the highest value is only $0.64270 \%$. This means that there is a significant un-diversifiable risk inherent in most of the J-REITs. Moreover, the average beta generated in the J-REITs', 
approximately 0.84143 , which is greater than M-REITs' beta value of 0.21224 . This explains the high systematic risk bear by J-REITs compared to M-REITs, which in other words it is more volatile against the marketmovement. Among all $57 \mathrm{~J}$-REITs, there are 15 different companies with beta value higher than 1 , whereas on the other hand M-REITs highest beta value is only valued at 0.36520 . The higher the beta value, the more the portfolio contributes towards the average systematic risk of the entire market. From the M-REITs' perspective however, the findings have shown that the volatility of each M-REIT against the market movement is relatively low compared to J-REITs as it contributes a much lower level of systematic risk. In conclusion, M-REITs has a relatively lower systematic risk and total risk in relative to J-REITs and it can be speculated that M-REITs' can be considered as a defensive investment portfolio as it has lower risk and less susceptible to market movement changes whereas J-REITs is a speculative investment portfolio which it has much more risk and higher degree of volatility against the market movement. In terms of R-squared, M-REITs has a much-lowered average value of approximately 0.05951 , whereas relatively J-REITs has a higher average value of 0.39949 , which is about 7 times higher than M-REITs' R-squared value. This can be concluded that the fund of J-REITs is highly diversified compared to M-REITs. For both J-REITs and M-REITs, the findings show that majority of the total risk is the unsystematic risk, in which it has a larger influencing factor over both REITs compared to systematic risk. However, the diversification measure of M-REITs' is almost one-fold higher than J-REITS', which M-REITs' and J-REITs' is valued at 0.94049 and 0.60051 respectively. For M-REITs', most of the diversification value is at least approximately 0.84 and above, which in otherwords means that most M-REITs have high diversification value and has greateropportunities for diversification. On the other hand, J-REITs have distinctive difference between the highest value REIT, which is Daiwa House REIT Investment Corporation, valued at 29.69231, and the lowest value, Mitsubishi Estate Logistics REIT InvestmentCorporation valued at 1.41898 . This implies that J-REITs has significantly loweropportunities for diversification compared to M-REITs.

\section{Sharpe, Treynor and Jensen's Alpha Ratio Analysis of M-reits' and J-reits' Respectively.}

In Table 3, Table 3.1 and Table 3.2, from the Sharpe ratio aspect, M-REITs has a higherratio compared to J-REITs, valued at 0.34647 compared with J-REITs' average REITs'Sharpe ratio at 0.16901 . It can be concluded that the overall performance of M-REITsis comparatively more attractive compared to J-REITs because of its Sharpe Ratio beinghigher than the other. In MREITs, Sunway Real Estate Investment Trust performed best, contributing 0.76650 in Sharpe ratio whereas Hektar Real Estate Investment Trustunderperformed against the overall average Sharpe ratio at 0.11230 . That being said, allof the M-REITs portfolio does not yield a negative ratio return, whereas on the other hand, J-REITs have 8 out of 57 REITs with negative values, which in other words meansthat it underperformed against the investments which generates risk free rate of return, hence the negative value ( $r f>r i)$.

While both Treynor Ratio records an average positive value of Treynor Ratio, M-REITs' are relatively better than J-REITs', which both valued at 0.56422 and 0.11397 respectively. In MREITs, the REIT with the highest Treynor Ratio is Al-'Aqar Healthcare REIT, standing at 1.01897, and not surprisingly M-REITs does not record any negative Treynor Ratio. On the other hand, J-REITs have the same 8 out 57 REITs that generates a negative value ratio, which indicates that the REITs have been underperformed against the investments which generates risk free rate of return, or in other words underperformed against the market benchmark. According to the table, J- REITs lowest value of Treynor Ratio stands at -0.31262 by Nippon Healthcare Investment Corporation, and the highest value stands at merely 0.76097 by Marimo Regional 
Revitalization REIT,Inc. M-REITs have been generating an average negative Jensen Alpha, 0.02858 , whereas J-REITs stay slightly above 0 , valued at 0.00076 . J-REITs recorded a higher Jensen Alpha ratio as compared to M-REITs, only 18 out of 57of J-REITs yield a negative value, which in the other words means that 39 of J-REITs outperformed against the benchmark of Tokyo Stock Exchange REIT Index. On the other hand, M-REITs, which average yields a negative return value, and have none REITs higher than the 0 value, have all underperformed against the KLPR KL PropertyIndex. In addition to that, there are still some J-REITs that yield negative Jensen Alpha ratio, in which some of it included are Nippon Healthcare Investment Corporation, Mitsubishi Estate Logistics REIT Investment Corporation, and Healthcare \& Medical Investment Corporation. However, in comparison to M-REITs who have all negative Jensen Alpha values, J-REITs outperformed relatively. In sum, J-REITs performed much better against the benchmark of market portfolio compared to M-REITs.

\section{Conclusion and Implications}

This research was conducted to compare and analyze the overall performance between 2 distinctive REITs, which is Malaysia, M-REITs and Japan, J-REITs, by applying risk-adjusted measures of Sharpe Ratio, Treynor Ratio and Jensen's Alpha. The research alsocompared and contrast risk diversification effectiveness of both M-REITs and J-REITs by using the diversifiability measure. For both REITs, the study period is from $4^{\text {th }}$ January 2008 to the last date $29^{\text {th }}$ December 2017. Results indicated between M-REITs and J-REITs, the overall average weekly return of M-REITs is higher than J-REITs, revealing that M-REITs outperformed J-REITs. Applying the Sharpe ratio, Treynor Ratio, and Jensen's Alpha, on average, M-REITs performed better in two of three performance measures, yielding positive results in all Sharpe and Treynor Ratio whilst yielding negative results in Jensen's Alpha. While M-REITs were the defensive investment portfolio to consider, the negative Jensen's Alpha value provided evidence that it does not earn any excess returns and it is not earning the proper return for its levelof risk. However, M-REITs do generate a better return than investment with risk free rate of returns in Malaysia as compared to J-REITs in Japan due to its high Sharpe and Treynor ratio. According to Sharpe Ratio, all M-REITs' achieved a positive Sharpe Ratio value in contrast to JREITs' 8 out of 57 REITs which recorded negative returns Ican be concluded that overall J-REITs gained lesser returns as compared to risk free rate of returns against the volatility of the portfolio. On the other hand, Treynor ratio resultsindicated that all M-REITs have gained positive Treynor values, while J-REITs yielded 8 out of 57 REITs with negative results. This revealed that J-REITs do not perform up to a risk-free rate level against the market risk, beta. Between M-REITs and J-REITs, the positive ratios of M-REITs indicated that they are able to gain better returns in compared to risk free rate. Besides, based on Jensen's Alpha, all M-REITs have yieldeda negative value return. It is observed that M-REIT underperformed against the KLPR KL Property Index. However, on the other hand, only 18 out of 57 of J-REITs have negative alpha values, on average they have shown a positive alpha value which in otherwords, they outperformed the Tokyo Stock Exchange REIT Index.

The risk features of M-REITs and J-REITs are compared according to the data given. Firstly, the total risk of M-REITs is lower than J-REITs. The Beta values for both M-REITs and J-REITs are less than 1, implying that both REITs are less risky or less volatile against market movement. Besides that, M-REITs have a lower R-squared valueas compared to J-REITs, which in other words means that M-REITs are poorly diversified than J-REITs. In turn, data suggest that MREITs have more diversified opportunities. M-REITs have a higher diversification measure as compared to J-REITs, which suggests that M-REITs may have better risk diversification benefits. 
In a nutshell, the findings suggest that low-risk appetite investors would prefer investing in $\mathrm{M}$ REITsrather than J-REITs, because they carry a lower risk. Moreover, M-REITs outperformed their risk-free rate of returns and also KLPR KL Property. In conclusion, investors should make careful consideration and plan their investing strategies by evaluating the market trend with the essential financial analysis of the market movement. In addition to that, the REITs' nature of investments offers a certain protection against capital loss against the volatility of the market as well as the economy.

The purpose of this study is to look in depth into the transparency of both M-REITs andJ-REITs for the readers to understand the risk it would take to invest in both REITs by providing a variety of different but meaningful quantitative evaluation of the past performance of both Malaysia Real Estate Investment Trust and Japan Real Estate Investments Trust. However, there are many other factors investors should also take into account when they choose which market to invest in that were not included into this research, which are intangible qualities like corporate management, trust management, growth strategy and the asset quality of each REITs. All these qualities have to be carefully evaluated by the investors so that it will provide a better insight and a better overall picture on the performance in order for the investor to make a careful yet preciseinvestment decision.

Table 1. Major Findings on Hypotheses Testing

\begin{tabular}{|c|c|c|c|}
\hline No. & Hypotheses & Findings & Co \\
\hline \multirow[t]{2}{*}{ 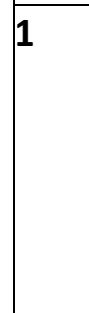 } & $\begin{array}{l}\text { HHoo: M-REITs' } \beta>\text { J-REITs' } \beta \text { (M-REITs' } \\
\text { have higher Beta [market risk] } \\
\text { compared toJ-REITs) }\end{array}$ & $\begin{array}{l}\text { M-REITs' } \\
\text { Beta }(0.21224) \\
<\end{array}$ & Reject Ho \\
\hline & $\begin{array}{l}\text { HH11: M-REITs' } \beta<\text { J-REITs' } \beta \text { (M-REITs'] } \\
\text { have lower Beta [market risk] compared( } \\
\text { to J-REITs) }\end{array}$ & $\begin{array}{l}\text { J-REITs' Beta } \\
d(0.84143)\end{array}$ & $\begin{array}{l}\mathrm{Do} \\
\mathrm{H} 1\end{array}$ \\
\hline 2 & $\begin{array}{l}\text { HHoo: M-REITs' Rd < J-REITs' Rd (M-REITsn } \\
\text { have lower risk diversification benefits } \\
\text { compared to J-REITs) }\end{array}$ & $\begin{array}{lr}\text { SM-REITs' } & \text { Rc } \\
(0.94049) & > \\
\text { REITs' } & R_{0}\end{array}$ & \\
\hline & $\begin{array}{l}\text { HH11: M-REITs' Rd > J-REITs" Rd (M-REITs } \\
\text { have higher risk diversification } \\
\text { benefitscompared to J-REITs') }\end{array}$ & $(0.60051)$ & $\begin{array}{l}\text { Do not Reje } \\
\mathrm{H} 1\end{array}$ \\
\hline 3 & $\begin{array}{l}\text { HHoo: M-REITs' SR < J-REITs' SR (M-REITs } \\
\text { have lower Sharpe ratio compared td } \\
\text { J-REITs) }\end{array}$ & $\begin{array}{ll}\begin{array}{l}\text { M-REITs' } \\
(0.34647)> \\
\text { J-REITs' SR }\end{array} & \text { SR }\end{array}$ & \\
\hline & $\begin{array}{l}\text { HH11: M-REITs' SR > J-REITs' SR (M- } \\
\text { REITs' have higher Sharpe ratid } \\
\text { compared } \\
\text { to J-REITs) }\end{array}$ & & $\begin{array}{l}\mathrm{Do} \\
\mathrm{H} 1\end{array}$ \\
\hline 4 & $\begin{array}{l}\text { HHoo: } \text { M-REITs' TR < J-REITs' TR (M- } \\
\text { REITs have lower Treynor ratid } \\
\text { compared toJ-REITs) }\end{array}$ & $\left\{\begin{array}{l}\text { M-REITs' TR } \\
(0.56422)> \\
\text { J-REITs' TR }\end{array}\right.$ & \\
\hline & $\begin{array}{l}\text { HH11: M-REITs' TR > J-REITs' TR (M-REITs } \\
\text { have higher Treynor ratio compared } \\
\text { to J-REITs) }\end{array}$ & 0. & $\begin{array}{l}\text { Do not Reje } \\
\text { H1 }\end{array}$ \\
\hline
\end{tabular}




\begin{tabular}{|c|c|c|}
\hline $\begin{array}{l}\text { HHoo: M-REITs' } \alpha i<J-R E I T s^{\prime} \alpha i(M-R E I T s \\
\text { have lower Jensen's Alpha compared } \\
\text { to J-REITs) }\end{array}$ & $\begin{array}{l}\text { SM-REITs' } \\
\text { O.02858) } \\
\text { REITs' }\end{array}$ & \begin{tabular}{l|l}
$\alpha \mathrm{\alpha i}$ & Do not Reje \\
$<\mathrm{J}$ & $\mathrm{HO}$ \\
$\alpha$ &
\end{tabular} \\
\hline $\begin{array}{l}\text { HH11: M-REITs' } \alpha i>\text { J-REITs' } \alpha i \text { (M-REITs } \\
\text { have higher Jensen's Alpha compared } \\
\text { to J-REITs) }\end{array}$ & $\$(0.00076)$ & Reject H1 \\
\hline
\end{tabular}

\section{References}

Brounen, D., \& De Koning, S. (2013). 50 years of real estate investment trusts: an international examination of the rise and performance of REITs. Journal of Real Estate Literature, 20(2), 197-223.

Chiang, M. C., Tsai, I. C., \& Sing, T. F. (2013). Are REITs a good shelter from financial crises? Evidence from the Asian markets. Journal of Property Investment \& Finance, 31(3), 237-253.

Cho, H. (2017). The Role of Sub-Sector REITS in Mixed-Asset Portfolios in Japan. Journal of Real Estate Literature, 25(2), 389-408.

Fama, E. F., \& French, K. R. (2004). The capital asset pricing model: Theory and evidence. Journal of economic perspectives, 18(3), 25-46.

Hamzah, A. H., \& Rozali, M. B. (2010). Empirical Investigation on the Performance of the Malaysian Real Estate Investment Trusts in Pre-Crisis, During Crisis and Post Crisis Period. International Journal of Economics and Finance, 2(2), pp. 62-69.

Jain, P. (2017). J-REIT market quality: impact of high frequency trading and the financial crisis. College of Business, University of Wyoming, Laramie.

Jalil, R. A., Ali, H. M., Razali, N., \& Yim, J. L. M. (2015). Optimal portfolio allocation of Malaysian real estate investment trusts during economic downturn. International Journal of Real Estate Studies, 9(2).

Jensen, M. C. (1968). The Performance of Mutual Funds in the Period 1945-1946. Journal of Finance, 23, 389-416.

Kim, H., Gu, Z., \& Mattila, A. S. (2002). Hotel real estate investment trusts' risk features and beta determinants. Journal of Hospitality \& Tourism Research, 26(2), 138-154.

Low, S. W., \& Johari, A. (2014). Risk-Adjusted Performance of Malaysian Real Estate Investment Trust Funds. Jurnal Pengurusan, 41, 3-11.

Markowitz, H. (1952). Portfolio Selection. The Journal of Finance, 7(1), 77-91. Miyakoshi, T., Shimada, J., \& Li, K. W. (2016). The impacts of the 2008 and 2011 crises on the Japan REIT market. Journal of the Japanese and International Economies, 41, 30-40.

Mohamad, N. E. A., \& Zolkifli, I. A. (2014). The Determinant Factors of Real Estate Investment Trust (REIT)'s Performance: Evidence from Asian REITs. Indonesian Capital Market Review, 6(1), 53-59

Moss, A., Clare, A., Thomas, S., \& Seaton, J. (2015). Trend following and momentum strategies for global REITs. Journal of Real Estate Portfolio Management, 21(1), 21-31.

Nawawi, A. H., Husin, A., Hadi, A. R. A., \& Yahya, M. H. (2010). Relationship and lead-lag effect between Asian Real Estate Investment Trusts (REITS) performance and Malaysian REIT market: Cointegration modelling. 2010 International Conference on Science and Social Research (CSSR 2010), 2010, pp. 522-527, doi: 10.1109/CSSR.2010.5773833.

Newell, G., \& Wen Peng, H. (2012). The significance and performance of Japan REITs in a mixed-asset portfolio. Pacific Rim Property Research Journal, 18(1), 21-34. 
Ng, C. Y. D., Leong, M. L., Lau, T. C., \& Abdul Rahim, F. (2018). A comparison on the performance and risk diversification benefits of real estate investment trusts in Malaysia and Singapore. In SHS Web of Conferences (Vol. 56, p. 04005). EDP Sciences.

Olanrele, O. O., Said, R., \& Daud, M. N. (2014). Benchmark for REIT performance in Malaysia using hedonic regression model. International Journal of Economics and Finance, 6(9), 165-176.

Olanrele, O. O., Said, R., \& Daud, M. N. (2015). Comparison of REIT dividend performance in Nigeria and Malaysia. African Journal of Business Management, 9(16), 608-614.

Ong, T. S., Teh, B. H., \& Chong, M. P. (2011). A Study on the Performance of Malaysian Real Estatelnvestment Trusts from 2005-2010 by using Net Asset Value Approach. International Journal of Trade, Economics and Finance, 2(1), 1-15.

Pham, A. K. (2012). The dynamics of returns and volatility in the emerging and developed Asian REIT markets. Journal of Real Estate Literature, 20(1), 79-96.

Sharpe, W. F. (1966). Mutual Fund Performance. Journal of Business. 39(S1): 119-138

Su, H. M., Huang, C. M., \& Pai, T. Y. (2010). The hybrid characteristic of REIT returns: evidence from Japanese and US States markets. Journal of Real Estate Literature, 18(1), 77-98.

Treynor, J. L. (1965). How to Rate management of Investment Funds. Harvard Business Review 43, pp. 63-75.

Table 2 - Summary of Risk features between M-Reits and J-Reits

\begin{tabular}{|l|l|l|}
\hline Risk Features (Average) & M-REITs & J-REITs \\
\hline Weekly Return & $0.2060 \%$ & $0.1918 \%$ \\
\hline Standard Deviation & $2.0573 \%$ & $3.6384 \%$ \\
\hline Total Risk & $4.38548 \%$ & $15.12367 \%$ \\
\hline Systematic Risk & $0.23722 \%$ & $6.29537 \%$ \\
\hline Unsystematic Risk & $4.14827 \%$ & $8.82830 \%$ \\
\hline R-Square & 0.05951 & 0.39949 \\
\hline Beta & 0.21224 & 0.84143 \\
\hline Diversifiability Measure & 0.94049 & 0.60051 \\
\hline
\end{tabular}


INTERNATIONAL JOURNAL OF ACADEMIC RESEARCH IN BUSINESS AND SOCIAL SCIENCES Vol. 11, No. 6, 2021, E-ISSN: 2222-6990 @ 2021 HRMARS

Table 2.1: Risk Features of M-REITs

\begin{tabular}{|c|c|c|c|c|c|c|c|}
\hline No & REITS & Beta $(\beta)$ & R-Square & Total Risl & kSystemat & iUnsystemati & Diversifiabilit \\
\hline & & & & & cRisk & c Risk & Measure \\
\hline 1 & $\begin{array}{ll}\text { Amanah } & \text { Harta } \\
\text { Tanah PNB } & \end{array}$ & 0.22226 & 0.05886 & 4.51170 & 0.26558 & 4.24612 & 0.94114 \\
\hline 2 & $\begin{array}{l}\text { Al-'Aqar Healthcare } \\
\text { REIT }\end{array}$ & 0.12343 & 0.01646 & 4.98091 & 0.08197 & 4.89894 & 0.98354 \\
\hline 3 & $\begin{array}{l}\text { AmFirst Real Estate } \\
\text { Investment Trust }\end{array}$ & 0.23635 & 0.12452 & 2.40998 & 0.30008 & 2.10990 & 0.87548 \\
\hline 4 & $\begin{array}{l}\text { AmanahRaya Rea } \\
\text { Estate Investment } \\
\text { Trust }\end{array}$ & 0.12063 & 0.02216 & 3.56635 & 0.07902 & 3.48733 & 0.97784 \\
\hline 5 & $\begin{array}{l}\text { Atrium Real Estate } \\
\text { Investment Trust }\end{array}$ & 0.13296 & 0.04224 & 2.24505 & 0.09483 & 2.15022 & 0.95776 \\
\hline 6 & $\begin{array}{l}\text { Axis Real Estate } \\
\text { Investment Trust }\end{array}$ & 0.25158 & 0.06230 & 5.45716 & 0.34000 & 5.11715 & 0.93770 \\
\hline 7 & $\begin{array}{l}\text { CapitaLand } \\
\text { Malaysia MallTrust }\end{array}$ & 0.21954 & 0.02242 & 7.82562 & 0.17542 & 7.65019 & 0.97758 \\
\hline 8 & $\begin{array}{l}\text { Hektar Real Estate } \\
\text { Investment Trust }\end{array}$ & 0.11844 & 0.01435 & 5.28984 & 0.07591 & 5.21393 & 0.98565 \\
\hline 9 & $\begin{array}{l}\text { IGB Real Estate } \\
\text { Investment Trust }\end{array}$ & 0.22541 & 0.04259 & 3.66354 & 0.15604 & 3.50750 & 0.95741 \\
\hline 10 & $\begin{array}{l}\text { KLCC Real Estate } \\
\text { Investment Trust }\end{array}$ & 0.36520 & 0.09467 & 7.58227 & 0.71779 & 6.86449 & 0.90533 \\
\hline 11 & MRCB-Quill REIT & 0.22846 & 0.08138 & 3.44532 & 0.28038 & 3.16494 & 0.91862 \\
\hline 12 & $\begin{array}{l}\text { Sunway Real Estate } \\
\text { Investment Trust }\end{array}$ & 0.25 & 0.05434 & 4.37654 & 0.23782 & 4.13872 & 0.94566 \\
\hline 13 & $\begin{array}{l}\text { Pavilion Real Estate } \\
\text { Investment Trust }\end{array}$ & 0.22691 & 0.02557 & 5.92869 & 0.15158 & 5.77711 & 0.97443 \\
\hline 14 & $\begin{array}{l}\text { Tower Real Estate } \\
\text { Investment Trust }\end{array}$ & 0.28208 & 0.16004 & 2.67074 & 0.42742 & 2.24331 & 0.83996 \\
\hline 15 & $\begin{array}{l}\text { UOA Real Estate } \\
\text { Investment }\end{array}$ & 0.22217 & 0.07005 & 3.79371 & 0.26576 & 3.52795 & 0.92995 \\
\hline 16 & YTL Hospitality REIT & T0.16477 & 0.06026 & 2.42033 & 0.14584 & 2.27449 & 0.93974 \\
\hline & Average & 0.21224 & 0.05951 & 4.38548 & 0.23722 & 4.14827 & 0.94049 \\
\hline
\end{tabular}


INTERNATIONAL JOURNAL OF ACADEMIC RESEARCH IN BUSINESS AND SOCIAL SCIENCES Vol. 11, No. 6, 2021, E-ISSN: 2222-6990 @ 2021 HRMARS

Table 2.2: Risk Features of J-REITs

\begin{tabular}{|c|c|c|c|c|c|c|c|}
\hline No & REITS & Beta $(\beta)$ & R-Square & eTotal Risk & Systemati & Unsystem & tDiversifiability \\
\hline & & & & & cRisk & icRisk & Measure \\
\hline 1 & $\begin{array}{ll}\text { Nippon } & \text { Building } \\
\text { Fund Inc. } & \end{array}$ & g1.05948 & 0.74450 & 16.44993 & 12.24700 & 4.20294 & 0.25550 \\
\hline 2 & $\begin{array}{l}\text { Japan Real Estate } \\
\text { Investment } \\
\text { Corporation }\end{array}$ & 1.08694 & 0.72995 & 17.65861 & 12.88997 & 4.76864 & 0.27005 \\
\hline 3 & $\begin{array}{l}\text { Japan Retail Func } \\
\text { Investment } \\
\text { Corporation }\end{array}$ & $\mathrm{d} 1.11227$ & 0.68302 & 19.76195 & 13.49771 & 6.26423 & 0.31698 \\
\hline 4 & ORIX JREIT Inc. & 1.08720 & 0.69376 & 18.58899 & 12.89628 & 5.69271 & 0.30624 \\
\hline 5 & $\begin{array}{l}\text { Japan Prime Realt } \\
\text { Investment } \\
\text { Corporation }\end{array}$ & 1.27053 & 0.69916 & 25.19073 & 17.61225 & 7.57847 & 0.30084 \\
\hline 6 & $\begin{array}{l}\text { Premier Investmen } \\
\text { Corporation }\end{array}$ & to.96169 & 0.29050 & 34.73544 & 10.09050 & 24.64494 & 0.70950 \\
\hline 7 & TOKYU REIT, Inc. & 1.13078 & 0.69682 & 20.02077 & 13.95087 & 6.06991 & 0.30318 \\
\hline 8 & $\begin{array}{l}\text { Global One Rea } \\
\text { Estate Investmen } \\
\text { Corporation }\end{array}$ & 0.96512 & 0.55156 & 18.42540 & 10.16264 & 8.26276 & 0.44844 \\
\hline 9 & $\begin{array}{ll}\text { United } & \text { Urbar } \\
\text { Investment } & \\
\text { Corporation } & \\
\end{array}$ & 0.87776 & 0.57507 & 14.61748 & 8.40603 & 6.21146 & 0.42493 \\
\hline 10 & $\begin{array}{l}\text { MORI TRUST Sogc } \\
\text { Reit, Inc. }\end{array}$ & 0.83063 & 0.55106 & 13.66028 & 7.52767 & 6.13261 & 0.44894 \\
\hline 11 & $\begin{array}{l}\text { Invincible } \\
\text { Investment } \\
\text { Corporation }\end{array}$ & 0.86412 & 0.23567 & 34.56931 & 8.14695 & 26.42235 & 0.76433 \\
\hline 12 & $\begin{array}{l}\text { Frontier Real Estate } \\
\text { Investment } \\
\text { Corporation }\end{array}$ & 0.77830 & 0.44499 & 14.85217 & 6.60909 & 8.24308 & 0.55501 \\
\hline 13 & $\begin{array}{l}\text { HEIWA REAL ESTATE } \\
\text { REIT, } \\
\text { Inc. }\end{array}$ & 1.07636 & 0.43907 & 28.78908 & 12.64028 & 16.14880 & 0.56093 \\
\hline 14 & $\begin{array}{l}\text { Japan Logistics Fund } \\
\text { Inc. }\end{array}$ & 0.69160 & 0.37541 & 13.90102 & 5.21858 & 8.68245 & 0.62459 \\
\hline 15 & \begin{tabular}{|l} 
Fukuoka \\
Corporation
\end{tabular} & 0.81344 & 0.52932 & 13.63855 & 7.21922 & 6.41933 & 0.47068 \\
\hline 16 & $\begin{array}{ll}\text { Kenedix } & \text { Office } \\
\text { Investment } \\
\text { Corporation }\end{array}$ & 1.40471 & 0.42310 & 50.88238 & 21.52852 & 29.35386 & 0.57690 \\
\hline 17 & $\begin{array}{l}\text { Ichigo Office REIT } \\
\text { Investment } \\
\text { Corporation }\end{array}$ & 0.65409 & 0.18893 & 24.70724 & 4.66791 & 20.03932 & 0.81107 \\
\hline
\end{tabular}


INTERNATIONAL JOURNAL OF ACADEMIC RESEARCH IN BUSINESS AND SOCIAL SCIENCES Vol. 11, No. 6, 2021, E-ISSN: 2222-6990 @ 2021 HRMARS

\begin{tabular}{|c|c|c|c|c|c|c|c|}
\hline 18 & \begin{tabular}{|ll} 
Daiwa & Office \\
Investment & \\
Corporation &
\end{tabular} & 1.34148 & 0.40964 & 47.93036 & 19.63401 & 28.29635 & 0.59036 \\
\hline 19 & $\begin{array}{l}\text { Hankyu Hanshin } \\
\text { REIT, Inc }\end{array}$ & 0.73896 & 0.51877 & 11.48430 & 5.95770 & 5.52660 & 0.48123 \\
\hline 20 & $\begin{array}{l}\text { Starts Proceed } \\
\text { Investment } \\
\text { Corporation }\end{array}$ & 0.62408 & 0.22331 & 19.02882 & 4.24933 & 14.77949 & 0.77669 \\
\hline 21 & $\begin{array}{l}\text { Daiwa House REIT } \\
\text { Investment } \\
\text { Corporation } \\
\end{array}$ & 0.74770 & 0.17042 & 35.79186 & 6.09955 & 29.69231 & 0.82958 \\
\hline 22 & $\begin{array}{ll}\text { Japan Hotel REIT } \\
\text { Investment } \\
\text { Corporation }\end{array}$ & 0.80339 & 0.26827 & 26.24948 & 7.04190 & 19.20758 & 0.73173 \\
\hline 23 & $\begin{array}{l}\text { Japan Renta } \\
\text { Housing } \\
\text { Investments } \\
\text { Inc. }\end{array}$ & 1.10999 & 0.32732 & 41.06812 & 13.44261 & 27.62552 & 0.67268 \\
\hline 24 & Japan Excellent, Inc. & 1.12602 & 0.65379 & 21.15901 & 13.83366 & 7.32536 & 0.34621 \\
\hline 25 & $\begin{array}{l}\text { Nippon } \\
\text { Accommodations } \\
\text { Fund Inc. } \\
\end{array}$ & 0.63064 & 0.35308 & 12.28944 & 4.33913 & 7.95031 & 0.64692 \\
\hline 26 & $\begin{array}{l}\text { MCUBS MidCity } \\
\text { Investment } \\
\text { Corporation }\end{array}$ & 1.03114 & 0.38129 & 30.42434 & 11.60053 & 18.82381 & 0.61871 \\
\hline 27 & $\begin{array}{ll}\text { Mori Hills } & \text { REIT } \\
\text { Investment } & \\
\text { Corporation } & \\
\end{array}$ & 0.89503 & 0.48250 & 18.11400 & 8.74007 & 9.37393 & 0.51750 \\
\hline 28 & $\begin{array}{l}\text { Industrial \& } \\
\text { Infrastructure } \\
\text { Fund Investment } \\
\text { Corporation }\end{array}$ & 0.82439 & 0.44531 & 16.65145 & 7.41498 & 9.23648 & 0.55469 \\
\hline 29 & $\begin{array}{l}\text { Advance Residence } \\
\text { Investment } \\
\text { Corporation }\end{array}$ & 0.94987 & 0.54637 & 8.50021 & 4.64425 & 3.85596 & 0.45363 \\
\hline 30 & $\begin{array}{ll}\text { Kenedix } & \text { Residentia } \\
\text { Next Investment } \\
\text { Corporation }\end{array}$ & 0.88037 & 0.50211 & 8.46552 & 4.25061 & 4.21491 & 0.49789 \\
\hline 31 & $\begin{array}{l}\text { Activia Properties } \\
\text { Inc. }\end{array}$ & 1.07848 & 0.63902 & 10.06192 & 6.42981 & 3.63210 & 0.36098 \\
\hline 32 & GLP J-REIT & 0.76095 & 0.37903 & 8.90385 & 3.37486 & 5.52898 & 0.62097 \\
\hline 33 & $\begin{array}{l}\text { Comforia } \\
\text { Residential REIT, Inc }\end{array}$ & 0.97425 & 0.53810 & 10.21203 & 5.49511 & 4.71693 & 0.46190 \\
\hline 34 & $\begin{array}{l}\text { Nippon } \\
\text { REIT, Inc. }\end{array}$ & 0.82814 & 0.46859 & 8.49944 & 3.98272 & 4.51672 & 0.53141 \\
\hline 35 & $\begin{array}{l}\text { Hoshino } \\
\text { REIT, Inc. }\end{array}$ & 0.75960 & 0.29901 & 8.58392 & 2.56671 & 6.01721 & 0.70099 \\
\hline
\end{tabular}


INTERNATIONAL JOURNAL OF ACADEMIC RESEARCH IN BUSINESS AND SOCIAL SCIENCES Vol. 11, No. 6, 2021, E-ISSN: 2222-6990 @ 2021 HRMARS

\begin{tabular}{|c|c|c|c|c|c|c|c|}
\hline 36 & One REIT, Inc. & 0.82950 & 0.34467 & 8.39213 & 2.89250 & 5.49963 & 0.65533 \\
\hline 37 & $\begin{array}{l}\text { AEON } \\
\text { Investment } \\
\text { Corporation }\end{array}$ & To.75163 & 0.24942 & 9.55702 & 2.38367 & 7.17335 & 0.75058 \\
\hline 38 & Hulic Reit, Inc. & 1.06792 & 0.51600 & 9.46456 & 4.88367 & 4.58089 & 0.48400 \\
\hline 39 & $\begin{array}{l}\text { NIPPON } \\
\text { Investment } \\
\text { Corporation }\end{array}$ & 0.81540 & 0.42265 & 6.92428 & 2.92654 & 3.99774 & 0.57735 \\
\hline 40 & $\begin{array}{l}\text { Invesco Office } \\
\text { REIT, Inc. }\end{array}$ & 0.70258 & 0.38584 & 5.75040 & 2.21873 & 3.53167 & 0.61416 \\
\hline 41 & $\begin{array}{l}\text { Nippon Healthcare } \\
\text { Investment } \\
\text { Corporation }\end{array}$ & 0.36047 & 0.10319 & 5.88998 & 0.60776 & 5.28222 & 0.89681 \\
\hline 42 & $\begin{array}{l}\text { Tosei } \\
\text { Investment } \\
\text { Corporation }\end{array}$ & it 0.68588 & 0.35251 & 6.13910 & 2.16412 & 3.97498 & 0.64749 \\
\hline 43 & $\begin{array}{l}\text { Sekisui House Reit } \\
\text { Inc. }\end{array}$ & 0.84874 & 0.51395 & 6.46964 & 3.32505 & 3.14458 & 0.48605 \\
\hline 44 & $\begin{array}{l}\text { Kenedix Retail REIT } \\
\text { Corporation }\end{array}$ & 0.89145 & 0.48583 & 7.67970 & 3.73105 & 3.94865 & 0.51417 \\
\hline 45 & $\begin{array}{l}\text { Healthcare } \\
\text { Medical Investment } \\
\text { Corporation }\end{array}$ & 0.79941 & 0.38513 & 7.83560 & 3.01769 & 4.81791 & 0.61487 \\
\hline 46 & $\begin{array}{l}\text { Samty Residentia } \\
\text { Investment } \\
\text { Corporation }\end{array}$ & 0.57659 & 0.32191 & 5.04754 & 1.62485 & 3.42269 & 0.67809 \\
\hline 47 & $\begin{array}{l}\text { Nomura Real Estate } \\
\text { Master Fund, Inc. }\end{array}$ & 1.03353 & 0.55293 & 7.58317 & 4.19298 & 3.39020 & 0.44707 \\
\hline 48 & $\begin{array}{l}\text { Ichigo Hotel REIT } \\
\text { Investment } \\
\text { Corporation }\end{array}$ & T0.43071 & 0.04043 & 19.02070 & 0.76895 & 18.25175 & 0.95957 \\
\hline 49 & $\begin{array}{ll}\text { LaSalle } & \text { LOGIPORT } \\
\text { REIT } & \\
\end{array}$ & 0.58407 & 0.24715 & 3.11776 & 0.77056 & 2.34720 & 0.75285 \\
\hline 50 & $\begin{array}{l}\text { Star Asia Investment } \\
\text { Corporation }\end{array}$ & 0.45723 & 0.13668 & 3.42418 & 0.46802 & 2.95616 & 0.86332 \\
\hline 51 & $\begin{array}{l}\text { Marimo Regiona } \\
\text { Revitalization REIT } \\
\text { Inc. }\end{array}$ & 0.39821 & 0.07171 & 3.17764 & 0.22788 & 2.94976 & 0.92829 \\
\hline 52 & $\begin{array}{lr}\text { Mitsui } \quad \text { Fudosan } \\
\text { Logistics }\end{array}$ & 0.96681 & 0.21817 & 6.06509 & 1.32324 & 4.74186 & 0.78183 \\
\hline 53 & $\begin{array}{l}\text { Ooedo Onsen Reit } \\
\text { Investment } \\
\text { Corporation }\end{array}$ & it 0.48746 & 0.07085 & 4.85282 & 0.34384 & 4.50898 & 0.92915 \\
\hline 54 & $\begin{array}{l}\text { SAKURA SOGO REIT } \\
\text { Investment } \\
\text { Corporation }\end{array}$ & 0.39607 & 0.07922 & 2.90618 & 0.23023 & 2.67595 & 0.92078 \\
\hline
\end{tabular}


INTERNATIONAL JOURNAL OF ACADEMIC RESEARCH IN BUSINESS AND SOCIAL SCIENCES Vol. 11, No. 6, 2021, E-ISSN: 2222-6990 @ 2021 HRMARS

\begin{tabular}{|l|l|l|l|l|l|l|l|}
\hline 55 & MIRAI Corporation & 0.74843 & 0.24846 & 3.62144 & 0.89979 & 2.72166 & 0.75154 \\
\hline 56 & $\begin{array}{l}\text { MORI TRUST Hote } \\
\text { Reit, Inc. }\end{array}$ & 0.62154 & 0.20527 & 3.04232 & 0.62449 & 2.41784 & 0.79473 \\
\hline 57 & $\begin{array}{l}\text { Mitsubishi Estate0.73810 } \\
\text { Logistic } \\
\text { REIT Investment } \\
\text { Corporation }\end{array}$ & 0.36099 & 2.22059 & 0.80160 & 1.41898 & 0.63901 \\
\hline Average & $\mathbf{0 . 8 4 1 4 3}$ & $\mathbf{0 . 3 9 9 4 9}$ & $\mathbf{1 5 . 1 2 3 6 7}$ & $\mathbf{6 . 2 9 5 3 7}$ & $\mathbf{8 . 8 2 8 3 0}$ & $\mathbf{0 . 6 0 0 5 1}$ \\
\hline
\end{tabular}

Table 3 - Summary of Performance between M-Reits and J-Reits

\begin{tabular}{|l|l|l|}
\hline Performance Ratio & M-REITs & J-REITs \\
\hline Sharpe Ratio & 0.34647 & 0.16901 \\
\hline Treynor Ratio & 0.56422 & 0.11397 \\
\hline Jensen's Alpha & -0.02858 & 0.00076 \\
\hline
\end{tabular}

Table 3.1: Sharpe, Treynor and Jensen's Alpha Ratio of M-REITs'

\begin{tabular}{|c|c|c|c|c|}
\hline No & REITs & Sharpe Ratio & Treynor Ratio & Jensen'sAlpha \\
\hline 1 & Amanah Harta Tanah PNB & 0.13951 & 0.21164 & -0.02879 \\
\hline 2 & Al-'Aqar Healthcare REIT & 0.35499 & 1.01897 & -0.03184 \\
\hline 3 & $\begin{array}{l}\text { AmFirst Real Estate } \\
\text { Investment Trust }\end{array}$ & 0.12794 & 0.13340 & -0.02853 \\
\hline 4 & $\begin{array}{l}\text { AmanahRaya Real Estate } \\
\text { InvestmentTrust }\end{array}$ & 0.20320 & 0.50498 & -0.03257 \\
\hline 5 & $\begin{array}{ll}\text { Atrium Real } & \text { Estate } \\
\text { Investment Trust }\end{array}$ & 0.44131 & 0.78948 & -0.03178 \\
\hline 6 & $\begin{array}{l}\text { Axis Real Estate Investment } \\
\text { Trust }\end{array}$ & 0.47665 & 0.70259 & -0.02659 \\
\hline 7 & $\begin{array}{l}\text { CapitaLand Malaysia Mall } \\
\text { Trust }\end{array}$ & 0.43648 & 0.88290 & -0.02746 \\
\hline 8 & $\begin{array}{l}\text { Hektar Real Estate Investment } \\
\text { Trust }\end{array}$ & t0.11230 & 0.34618 & -0.03277 \\
\hline 9 & $\begin{array}{l}\text { IGB Real Estate Investment } \\
\text { Trust }\end{array}$ & t0.28726 & 0.38721 & -0.02807 \\
\hline 10 & $\begin{array}{l}\text { KLCC Real Estate Investment } \\
\text { Trust }\end{array}$ & 0.51970 & 0.62204 & -0.02188 \\
\hline 11 & MRCB-Quill REIT & 0.16114 & 0.20783 & -0.02860 \\
\hline 12 & $\begin{array}{l}\text { Sunway Real } \\
\text { Investment Trust }\end{array}$ & 0.76650 & 0.99563 & -0.02588 \\
\hline 13 & $\begin{array}{l}\text { Pavilion } \quad \text { Real } \\
\text { Investment Trust }\end{array}$ & 0.36659 & 0.62445 & -0.02745 \\
\hline 14 & $\begin{array}{l}\text { Tower Real Estate Investment } \\
\text { Trust }\end{array}$ & 0.14893 & 0.13697 & -0.02669 \\
\hline 15 & UOA Real Estate Investment & 0.34729 & 0.48333 & -0.02827 \\
\hline 16 & YTL Hospitality REIT & 0.65380 & 0.97994 & -0.03015 \\
\hline
\end{tabular}


$-0.02858$

Table 3.2: Sharpe, Treynor and Jensen's Alpha Ratio of J-REITs'

\begin{tabular}{|c|c|c|c|c|}
\hline No & REITs & Sharpe Ratio & Treynor Ratio & Jensen's Alpha \\
\hline 1 & Nippon Building Fund Inc. & -0.00809 & -0.00492 & 0.00089 \\
\hline 2 & $\begin{array}{l}\text { Japan Real Estate Investment } \\
\text { Corporation }\end{array}$ & 10.00500 & 0.00307 & 0.00127 \\
\hline 3 & $\begin{array}{l}\text { Japan Retail Fund Investment } \\
\text { Corporation }\end{array}$ & 10.08995 & 0.05707 & 0.00231 \\
\hline 4 & ORIX JREIT Inc. & 0.10333 & 0.06505 & 0.00224 \\
\hline 5 & $\begin{array}{l}\text { Japan Prime Realty } \\
\text { Investment Corporation }\end{array}$ & 0.02299 & 0.01442 & 0.00288 \\
\hline 6 & $\begin{array}{ll}\text { Premier } & \text { Investment } \\
\text { Corporation } & \\
\end{array}$ & $1+0.03873$ & 0.03768 & 0.00183 \\
\hline 7 & TOKYU REIT, Inc. & 0.01953 & 0.01227 & 0.00183 \\
\hline 8 & $\begin{array}{l}\text { Global One Real Estate } \\
\text { Investment Corporation }\end{array}$ & -0.01723 & -0.01216 & 0.00030 \\
\hline 9 & $\begin{array}{l}\text { United Urban Investment } \\
\text { Corporation }\end{array}$ & to.18045 & 0.12477 & 0.00121 \\
\hline 10 & MORI TRUST Sogo Reit, Inc. & -0.00279 & -0.00197 & -0.00055 \\
\hline 11 & $\begin{array}{ll}\text { Invincible } & \text { Investment } \\
\text { Corporation } & \end{array}$ & 10.03813 & 0.04118 & 0.00139 \\
\hline 12 & $\begin{array}{l}\text { Frontier Real Estate } \\
\text { Investment Corporation }\end{array}$ & 0.10560 & 0.08301 & 0.00017 \\
\hline 13 & HEIWA REAL ESTATE REIT, Inc & c. 0.06848 & 0.05419 & 0.00248 \\
\hline 14 & Japan Logistics Fund, Inc. & 0.14600 & 0.12495 & -0.00012 \\
\hline 15 & Fukuoka REIT Corporation & 0.13216 & 0.09525 & 0.00049 \\
\hline 16 & $\begin{array}{l}\text { Kenedix Office Investment } \\
\text { Corporation }\end{array}$ & $1+0.04587$ & 0.03698 & 0.00537 \\
\hline 17 & $\begin{array}{l}\text { Ichigo Office REIT Investment } \\
\text { Corporation }\end{array}$ & 0.17329 & 0.20905 & 0.00067 \\
\hline 18 & $\begin{array}{l}\text { Daiwa Office Investment } \\
\text { Corporation }\end{array}$ & 10.04189 & 0.03432 & 0.00468 \\
\hline 19 & Hankyu Hanshin REIT, Inc & 0.06678 & 0.04862 & -0.00060 \\
\hline 20 & $\begin{array}{l}\text { Starts Proceed Investment } \\
\text { Corporation }\end{array}$ & 10.14903 & 0.16536 & -0.00008 \\
\hline 21 & $\begin{array}{l}\text { Daiwa House REIT Investment } \\
\text { Corporation }\end{array}$ & 0.30537 & 0.38787 & 0.00272 \\
\hline 22 & $\begin{array}{l}\text { Japan Hotel REIT Investment } \\
\text { Corporation }\end{array}$ & 0.31448 & 0.31837 & 0.00246 \\
\hline 23 & $\begin{array}{l}\text { Japan Rental } \\
\text { Investments Inc. }\end{array}$ & g0.05103 & 0.04677 & 0.00320 \\
\hline 24 & Japan Excellent, Inc. & 0.02552 & 0.01655 & 0.00190 \\
\hline
\end{tabular}


INTERNATIONAL JOURNAL OF ACADEMIC RESEARCH IN BUSINESS AND SOCIAL SCIENCES Vol. 11, No. 6, 2021, E-ISSN: 2222-6990 @ 2021 HRMARS

\begin{tabular}{|c|c|c|c|c|}
\hline 25 & $\begin{array}{l}\text { Nippon Accommodations } \\
\text { Fund Inc. }\end{array}$ & $\$ 0.25912$ & 0.22866 & -0.00003 \\
\hline 26 & $\begin{array}{l}\text { MCUBS MidCity Investment } \\
\text { Corporation }\end{array}$ & t0.03295 & 0.02798 & 0.00197 \\
\hline 27 & $\begin{array}{l}\text { Mori Hills REIT Investment } \\
\text { Corporation }\end{array}$ & 0.05367 & 0.04051 & 0.00069 \\
\hline 28 & $\begin{array}{l}\text { Industrial \& InfrastructureC } \\
\text { Fund Investment Corporation }\end{array}$ & 0.35927 & 0.28230 & 0.00187 \\
\hline 29 & $\begin{array}{l}\text { Advance ResidenceC } \\
\text { Investment Corporation }\end{array}$ & 0.57687 & 0.28108 & 0.00137 \\
\hline 30 & $\begin{array}{l}\text { Kenedix Residential Nextc } \\
\text { Investment Corporation }\end{array}$ & 0.47677 & 0.25013 & 0.00069 \\
\hline 31 & Activia Properties Inc. & 0.52452 & 0.24490 & 0.00169 \\
\hline 32 & GLP J-REIT & 0.49329 & 0.30707 & 0.00066 \\
\hline 33 & Comforia Residential REIT, IndC & 0.32291 & 0.16814 & 0.00139 \\
\hline 34 & Nippon Prologis REIT, Inc. & 0.43836 & 0.24498 & 0.00095 \\
\hline 35 & Hoshino Resorts REIT, Inc. & 0.50836 & 0.31126 & 0.00150 \\
\hline 36 & One REIT, Inc. & 0.19263 & 0.10679 & 0.00036 \\
\hline 37 & $\begin{array}{l}\text { AEON REIT Investment } \\
\text { Corporation }\end{array}$ & 0.07564 & 0.04938 & -0.00091 \\
\hline 38 & Hulic Reit, Inc. & 0.20063 & 0.09175 & 0.00174 \\
\hline 39 & $\begin{array}{l}\text { NIPPON REIT Investment } \\
\text { Corporation }\end{array}$ & 0.28527 & 0.14614 & 0.00065 \\
\hline 40 & Invesco Office J-REIT, Inc. & 0.13017 & 0.07053 & -0.00095 \\
\hline 41 & $\begin{array}{l}\text { Nippon Healthcare- } \\
\text { Investment Corporation }\end{array}$ & -0.29251 & -0.31262 & -0.00623 \\
\hline 42 & $\begin{array}{l}\text { Tosei Reit Investmentc } \\
\text { Corporation }\end{array}$ & 0.11675 & 0.06695 & -0.00039 \\
\hline 43 & Sekisui House Reit, Inc. & 0.05029 & 0.02392 & 0.00014 \\
\hline 44 & $\begin{array}{|lll|}\begin{array}{l}\text { Kenedix } \\
\text { Corporation }\end{array} & \text { Retail } & \text { REIT- } \\
\end{array}$ & $\mathrm{T}-0.00591$ & -0.00292 & 0.00020 \\
\hline 45 & $\begin{array}{l}\text { Healthcare \& Medica } \\
\text { Investment Corporation }\end{array}$ & -0.21528 & -0.11967 & -0.00252 \\
\hline 46 & $\begin{array}{l}\text { Samty Residential Investment } \\
\text { Corporation }\end{array}$ & 0.01890 & 0.01169 & -0.00195 \\
\hline 47 & $\begin{array}{l}\text { Nomura Real Estate Master- } \\
\text { Fund, Inc. }\end{array}$ & $1-0.06165$ & -0.02608 & 0.00000 \\
\hline 48 & $\begin{array}{l}\text { Ichigo Hotel REIT Investment } \\
\text { Corporation }\end{array}$ & 0.15125 & 0.24312 & -0.00042 \\
\hline 49 & LaSalle LOGIPORT REIT & 0.25492 & 0.12234 & -0.00047 \\
\hline 50 & $\begin{array}{l}\text { Star Asia } \\
\text { Corporation }\end{array}$ & t0.44725 & 0.28734 & -0.00005 \\
\hline 51 & Marimo & 1.07086 & 0.76097 & 0.00191 \\
\hline
\end{tabular}


INTERNATIONAL JOURNAL OF ACADEMIC RESEARCH IN BUSINESS AND SOCIAL SCIENCES Vol. 11, No. 6, 2021, E-ISSN: 2222-6990 @ 2021 HRMARS

\begin{tabular}{|l|l|l|l|l|}
\hline & \begin{tabular}{l} 
Revitalization REIT, Inc. \\
\hline 52
\end{tabular} & $\begin{array}{l}\text { Mitsui Fudosan Logistics Park } 0.48042 \\
\text { Inc. }\end{array}$ & 0.19426 & 0.00489 \\
\hline 53 & $\begin{array}{l}\text { Ooedo Onsen Reit Investment0.12461 } \\
\text { Corporation }\end{array}$ & 0.08939 & -0.00152 \\
\hline 54 & $\begin{array}{l}\text { SAKURA SOGO REIT } 0.44746 \\
\text { Investment Corporation }\end{array}$ & 0.30574 & -0.00073 \\
\hline 55 & MIRAI Corporation & 0.37039 & 0.14950 & 0.00169 \\
\hline 56 & \begin{tabular}{l} 
MORI TRUST Hotel Reit, Inc. \\
\hline 57
\end{tabular} & $\begin{array}{l}\text { Mitsubishi Estate Logistic REIT-0.04019 } \\
\text { Investment Corporation }\end{array}$ & 0.01790 & -0.00067 \\
\hline Average of J-REITs' & $\mathbf{0 . 1 6 9 0 1}$ & $\mathbf{0 . 1 1 3 9 7}$ & $\mathbf{0 . 0 0 0 0 7 6}$ \\
\hline
\end{tabular}

